\title{
Kazak Chinese
}

National Cancer Institute

\section{Source}

National Cancer Institute. Kazak Chinese. NCI Thesaurus. Code C158175.

A Chinese person from the Kazak ethnic group. 